\title{
Disain Struktural Dalam Perspektif Kearifan Lokal (Local Wisdom Perspective) pada Rumah Tradisional Melayu di Kota Sambas Kalimantan Barat
}

\author{
Zairin Zain'; Indra Wahyu Fajar² \\ ${ }^{1}$ Dosen pada Program Studi Arsitektur Fakultas Teknik dan Peneliti pada Pusat Studi Disain Universitas Tanjungpura, Indonesia \\ ${ }^{2}$ Mahasiswa,Program Studi Arsitektur, Fakultas Teknik Universitas Tanjungpura,Indonesia \\ zairin.zain@gmail.com
}

\begin{abstract}
ABSTRAK
Rumah itu dibangun untuk memenuhi kebutuhan fisik dan spiritual bagi penghuni. Ini berarti bahwa fungsi rumah secara fisik dibangun untuk mempertahankan hidup mereka dari ancaman lingkungan seperti iklim, cuaca atau hewan liar, sementara rumah juga diperuntukkan untuk kebutuhan rohani mereka dengan memfasilitasi interaksi antara penghuni di rumah atau interaksi dengan orang di luar rumah. Untuk itu, menarik untuk mendalami kearifan lokal yang hidup di masyarakat tradisional di Kota Sambas Kalimantan Barat, melalui pemahaman disain struktural dari elemen-elemen tempat tinggal tersebut. Disain struktural bangunan dikerjakan dalam memenuhi tujuan-tujuan untuk safety, values, fitness, compatibility dan flexibility. Dari hasil penelitian ini ditemukan bahwa disain struktural rumah tradisional Melayu di kota Sambas dibangun dengan Tujuan Safety diperoleh dari keadaan yang memperhatikan kedominanan, proporsi dan keseimbangan; Tujuan Value diperoleh dari perhatian terhadap konstruksi ruang, keterhubungan ruang, susunan dan perletakan kolom; Tujuan Fitness diperoleh dari pemilihan dan pola struktur; Tujuan Compatibility diperoleh dari perhatian terhadap pemilihan material, orientasi bangunan dan bentuk-bentuk struktur ruang; sedangkan Tujuan Flexibility diperoleh dari susunan dan keterkaitan ruang serta pemilihan sistem struktur.
\end{abstract}

Kata kunci: disain struktural, rumah tradisional, kearifan lokal

\begin{abstract}
The house was built to meet the physical and spiritual needs of the occupants. This means that the physical functions of house was bulit to maintain their living from environmental threats such as climate, weather or wild animals, while the house as well intended for their spiritual needs to facilitating the interaction between the occupants in the house or interaction with people outside the house. For that, it is interesting to explore the local wisdom that growing in traditional people of the Sambas town West Kalimantan, through an understanding of the structural design of the house elements. Structural design of the building is done to fulfill the objectives of safety, values, fitness, compatibility and flexibility. From the results of this study found that the structural design of the Malay traditional house in Sambas town was built with the aim of Safety obtained from the state of attention to dominance, proportion and balance; the aim of Value obtained from the state of attention to the construction of space, the connectedness of space, arrangement and placement of columns; the aim of Fitness obtained from the state of attention to the selection and patterns of structures; the aim of Compatibility obtained from the state of attention to the material selection, building orientation and the forms of spatial structure; while the aim of Flexibility is obtained from the state of attention to the composition and space connectedness and the structural system.
\end{abstract}

Keywords: structural design, traditional house, local wisdom

\section{Pendahuluan}

Menurut Zain (2012a), Sebuah rumah memiliki peran penting dalam perjalanan kehidupan manusia di dunia. Rumah itu dibangun untuk memenuhi kebutuhan fisik dan spiritual bagi penghuni. Ini berarti bahwa fungsi rumah secara fisik untuk mempertahankan hidup mereka dari ancaman lingkungan seperti iklim dan cuaca atau hewan liar, sementara rumah juga sebagai diperuntukkan untuk kebutuhan rohani mereka dengan memfasilitasi interaksi antara penghuni di rumah atau interaksi dengan orang di luar rumah.

Arsitektur Melayu merupakan aset karya arsitektur tradisional nusantara. Sebagai salah satu bagian esensial dan salah satu khazanah serta warisan yang perlu digali secara mendalam. Menurut Almudra (2004) Kemajuan teknologi, 
tingkat pendidikan dan wawasan, tingkat sosial-ekonomi berpengaruh terhadap konsep, selera dan kebutuhan orang Melayu tentang rumah, sekaligus bentuk dan fungsi rumah Melayu. Arsitektur tradisional memiliki identitas budaya dan tersebar diseluruh Indonesia.

Zain (2013) menjelaskan bahwa rumah tradisional di kota Sambas yang masih bertahan hingga sekarang, seperti halnya rumah-rumah tradisional lain di Kalimantan Barat, erat kaitannya dengan sejarah kerajaan Sambas yang pernah jaya pada zaman dahulu. Di kota Sambas masih berdiri beberapa rumah tradisional dengan bentuk khas yang megah dan konstruksi yang masih mampu bertahan. Untuk itu, rumah tradisional ini perlu di jaga dan di pertahankan sebagai suatu aset karya arsitektur tradisional nusantara.

Penyesuaian pada rumah masyarakat lokal itu dapat dilihat dalam aplikasi mereka di rumah-rumah tradisional yang biasanya mengkaitkan bagian-bagian rumah dan ruang-ruang yang terbentuk dengan perkembangan budaya dalam masyarakat mereka (Zain, 2012b: 103).

Menurut Zain dan Fajar (2014), rumah Melayu di kota Sambas tidak hanya mempunyai 3 jenis berdasarkan bentuk atap melainkan mempunyai satu jenis lagi yang wujud ruang yakni Potong Lanting. Jenis ini memiliki bentuk atap yang sama dengan Potong Limas namun memiliki wujud ruang yang berbeda pada terasnya yang memiliki lapisan dinding yang menaungi ruang tersebut.

Masyarakat tradisional akan mengkaitkan dengan budaya lokal yang berisi pesan khusus pada fungsi kamar, seluruh bagian rumah atau fasilitas lainnya sebagai norma keturunan berharga yang dimiliki oleh masyarakat, dan diterapkan dalam penampilan fisik rumah. Untuk itu, menarik untuk mendalami kearifan lokal pada masyarakat tradisional di Kota sambas Kalimantan Barat, melalui pemahaman disain struktural tempat tinggal dan bagian-bagian rumah. Dari penerapan kearifan lokal pada disain struktural rumah tinggal tradisional akan mencerminkan nilai-nilai keluarga yang mendiami rumah tersebut dan sekaligus akan menjelaskan prinsip-prinsip dan norma-norma yang berlaku dalam masyarakat di Kota Sambas Kalimantan Barat.

\section{Kajian Literatur}

Arsitektur tradisional biasanya digunakan untuk menggambarkan praktikpraktik konstruksi atau konsep struktur dalam seni bangunan yang merupakan produk dari orang-orang profesional tidak terlatih, tetapi menghasilkan teknik-teknik konstruksi atau mengikuti pemahaman struktur yang pada dasarnya telah diterima oleh masyarakat sebagai sesuatu yang benar atau "di disain dengan cara terbaik" (Noble, 2007:5).

Selanjutnya Wahl (2007:

menjelaskan bahwa Bangunan struktur adalah dikendalikan (atau dikontrol) oleh aliran kekuatan fisik melalui saluran (atau rute) yang dibentuk oleh bahan-bahan resistif dalam rangka bangunan untuk melindungi struktur tiga-dimensi bangunan dari keruntuhan. The design of structures is personally enjoyable, visually and technically significant, and professionally satisfaying. Desain struktur secara khusus harus menyenangkan bagi aktivitas penggunanya, secara visual dan teknis harus signifikan memberikan jaminan keamanan, dan secara profesional akan memberikan kepuasan kepada penggunanya.

Lebih lanjut Wahl (2007: 8-9) menjelaskan tujuan desain struktural pada bangunan adalah:

- Safety, harus menyediakan tempat penampungan yang aman dan menjadi perlindungan dari bahaya bagi penghuni;

- Value, disain struktur harus menjadi nilai yang sesuai dengan keinginan penghuni;

- Fitness, struktur harus sesuai kondisi spesifik site bangunan, dan memenuhi persyaratan program sirkulasi internal dan fungsi pada bangunan;

- Compatibility, sistem struktural harus mampu terintegrasi dengan keseluruhan sistem internal dan eksternal bangunan;

- Flexibility, fleksibilitas kemampuan struktur dalam memprediksi kebutuhan fungsi terhadap masa utilitas bangunan dan kondisi site di masa depan.

\section{Metodologi Penelitian}

Penelitian dilakukan di Kampung Durian dan Kampung Dagang Timur Kota Sambas Kalimantan Barat. Obyek penelitian berada di tepi sungai dan tidak jauh dari komplek istana Sambas dengan pemilihan kasus yang didasarkan pada pertimbangan kondisi spesifik rumah tradisional. Sebagai obyek penelitian adalah rumah tradisional suku Melayu di kota Sambas dengan kondisinya masih baik dan dihuni dengan ciri struktur dan fasad bangunan yang tidak mengalami banyak perubahan.

Fokus penelitian ini adalah pengamatan terhadap disain struktur bangunan tradisional dengan melakukan pembagian terhadap struktur. Pembagian didasarkan atas struktur bawah, struktur tengah dan struktur atas. Berdasarkan penjelasan di atas, terdapat 3 rumah tradisional yang dijadikan sebagai kasus penelitian. Rumah tinggal yang dipilih sebagai kasus adalah bangunan bangunan tradisional dalam kondisi masih asli dan lokasi kasus tersebut terletak di Kampung Durian sebanyak 2 rumah (kasus I dan kasus II) dan di Kampung Dagang Timur sebanyak 1 rumah (kasus III). 


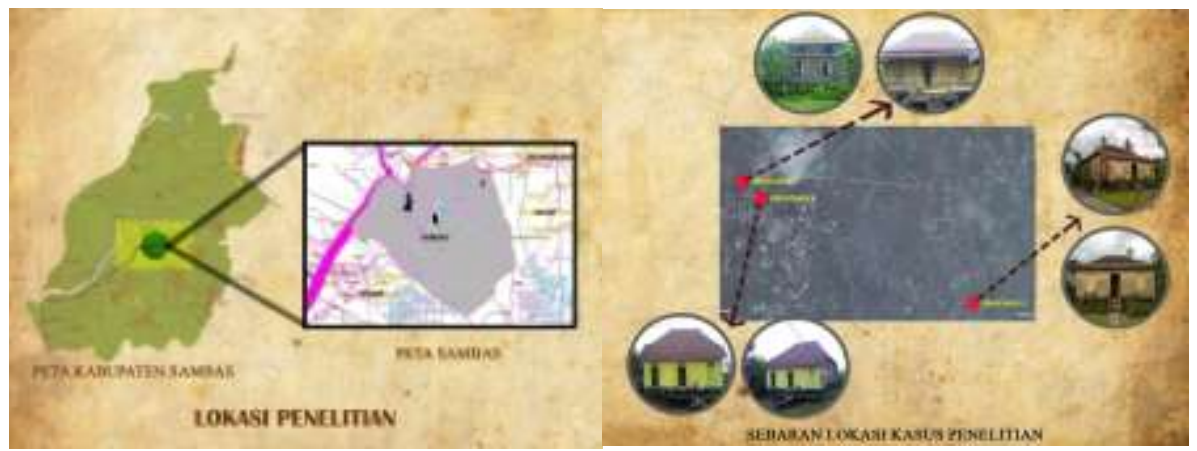

Gambar 1. Foto-foto obyek di sebaran lokasi penelitian

Sumber : Peta (Bappeda Kab. Sambas, 2012); Foto-foto (penulis, 2014)

Rumah kasus I dibangun pada tahun 1910-an terletak di kampung Durian bangunan ini berbentuk persegi dan memanjang ke belakang dengan fasad dan atap yang menghadap ke timur laut. Denah bangunan berbentuk simetris dengan 3 (tiga) buah bukaan di fasad.

Kasus I berada persis di pinggir sungai Sambas dengan orientasi ke arah sungai. Rumah induk berada 2 meter diatas permukaan tanah dengan pondasi yang terendam air. Tampak depan kasus I menghadap timur laut dan sungai Sambas. Kasus I memiliki suak (parit kecil) di sisi kiri rumah.

Rumah kasus II terletak di kampung Durian dan dibangun pada tahun 1908-an. Bangunan ini berbentuk persegi dan memanjang ke belakang dengan fasad dan atap yang menghadap ke timur laut.

Kasus il berada persis di pinggir sungai Sambas dengan orientasi ke arah sungai. Bangunan terdiri atas 2 (dua) bagian yaitu rumah induk dan rumah anak. Rumah induk berada 2 meter diatas permukaan tanah dengan pondasi yang terendam air. Orientasi bangunan kasus $\Pi$ menghadap ke timur laut dan menghadap sungai Sambas. Tanah di depan bangunan kasus II mengalami abrasi sehingga ada penambahan geratak (jembatan dari kayu) sepanjang 4 meter sebagai sirkulasi menuju ke rumah.

Rumah kasus III terletak di Kampung Dagang Timur dan didirikan pada hari minggu tanggal 14 bulan Jumaidil Awal tahun $1322 \mathrm{H}$ dan dipindahkan pada hari kamis tanggal 14 bulan Ramadhan $1324 \mathrm{H}$.

Kasus III berada persis di pinggir sungai Sambas dengan orientasi ke arah sungai. Bangunan terdiri atas 2 (dua) bagian yaitu rumah induk dan rumah anak. Orientasi bangunan kasus III menghadap ke Barat dan menghadap sungai Sambas. Bangunan kasus III mempunyai rumah anak. Rumah anak ini tidak difungsikan lagi karena sudah hancur seiring perkembangan zaman. Pada lantai bangunan induk menggunakan papan belian. Tidak mempunyai pelantaran depan tetapi mempunyai pelantaran belakang yang menghubungkan rumah induk dengan rumah anak. Untuk masuk ke rumah dihubungkan dengan tangga.

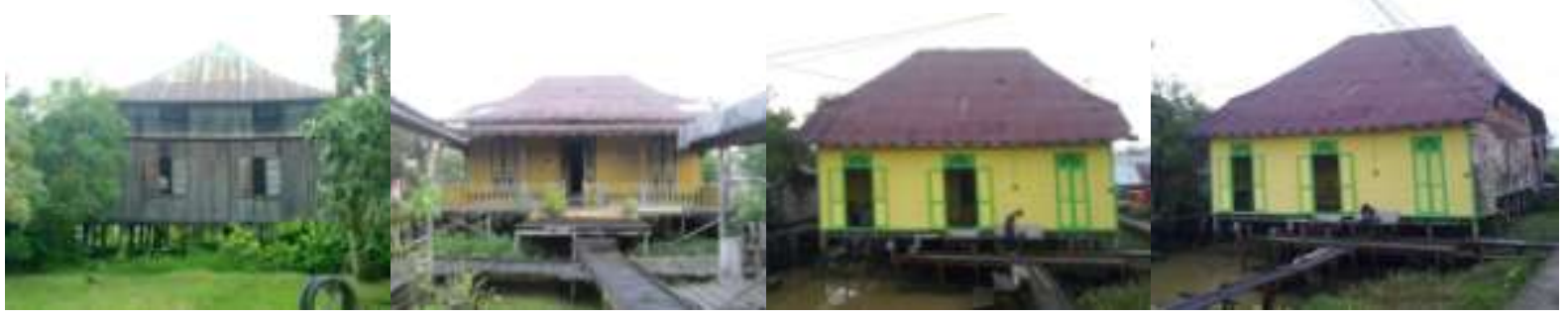

Kasus I

Kasus li

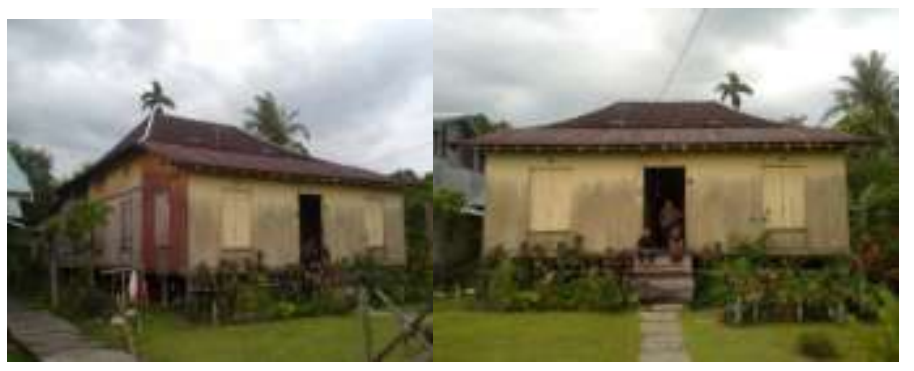

Kasus III

Gambar 2. Fasad depan dan samping bangunan yang menjadi kasus penelitian

Sumber : Penulis, 2013 


\section{Pembahasan}

Pembahasan dilakukan dengan
deskripsi tentang disain struktural bangunan berdasarkan hasil pengamatan di lapangan pada masing-masing kasus penelitian. Penjelasan dilakukan berdasarkan elemen struktur bangunan yang dibagi atas 3 bagian, yaitu struktur bawah (sub structure) berupa pondasi dan balok pengaku; struktur tengah (bottom side superstructure) berupa gelegar, lantai, rangka dan dinding serta balok pengaku: dan struktur atas (upper side super structure) berupa gelegar dan lantai parak, dinding parak, kuda-kuda dan atap.

\section{Struktur bawah (sub structure)}

Bagian Pondasi bangunan terdiri dari 3 bagian, yaitu tiang vertikal (tongkat), alas (galang), dan laci (kaling). Pondasi sebagai struktur bawah yang digunakan yakni pondasi berupa tongkat dengan galang menerus.

Gambar 3 menjelaskan denah pondasi kasus I, II dan III. Galang dipasang memanjang bangunan yang disesuaikan dengan posisi kuda-kuda dan permukaan atap. Dapat dilihat pondasi tongkat tambahan yang dipasang melintang bangunan digunakan untuk membantu kolom utama. Penambahan ini dilakukan untuk menghindari lendutan pada balok lantai akibat dari jarak antara kolom yang lebar (> $3.5 \mathrm{~m})$, sedangkan untuk jarak antara kolom yang tidak lebar $(<3.5 \mathrm{~m})$ tidak dipasang tongkat tambahan karena diasumsikan bahwa balok lantai mampu menahan beban yang diterima.

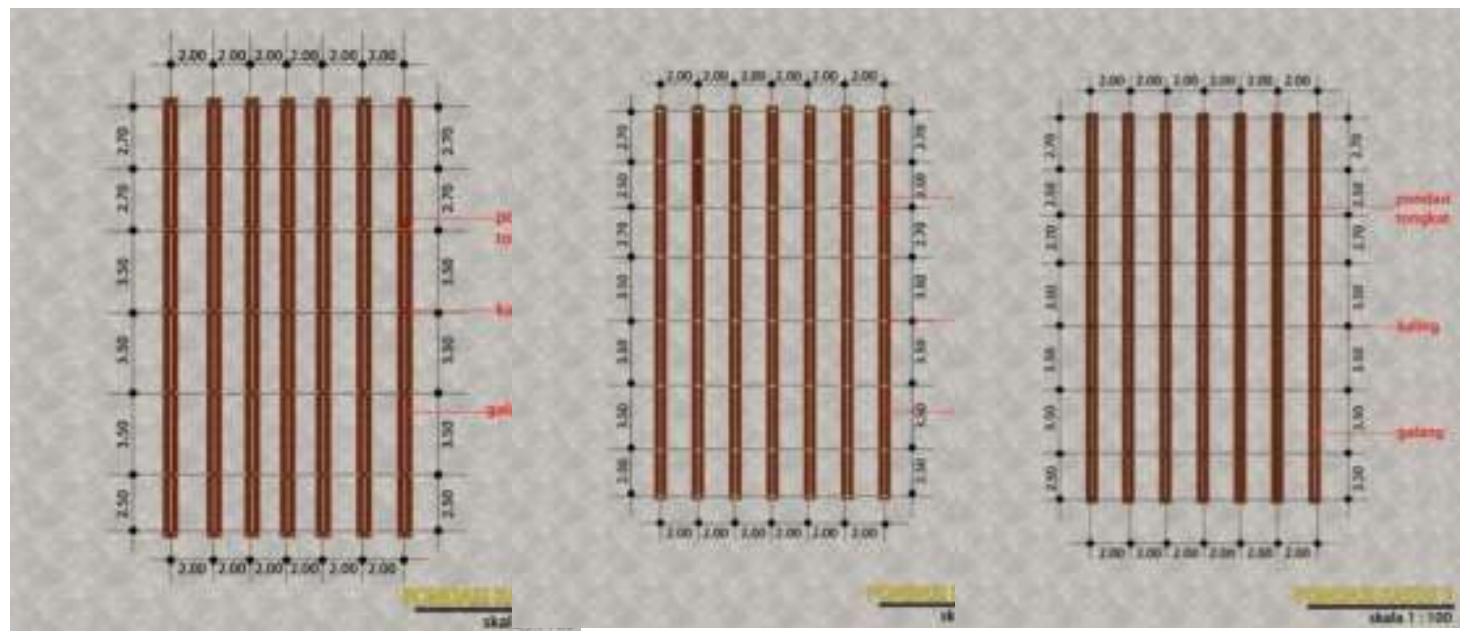

Gambar 3. Denah pondasi pada bangunan kasus I,II dan III Sumber : Penulis, 2013

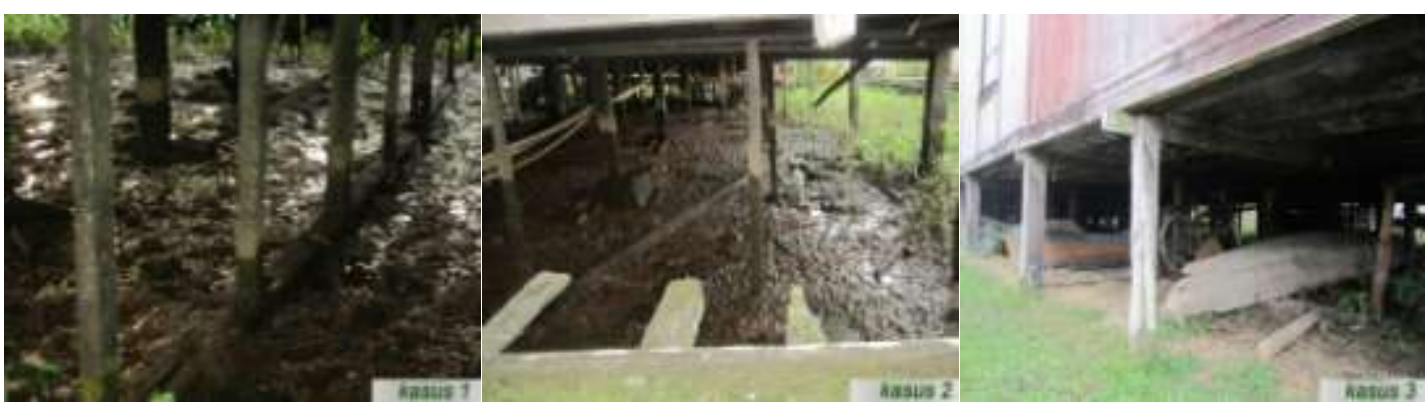

Gambar 4. Kondisi struktur bawah kasus I,II dan III Sumber : Penulis, 2013

Hasil pengamatan pada struktur pondasi, kondisi tongkat, galang, dan kaling pada semua kasus mengalami pelapukan sekitar $15 \mathrm{~cm}$ sampai $30 \mathrm{~cm}$ akibat jamur dan ditumbuhi tumbuhan lumut. Hal ini disebabkan karena bagian ini mengalami kondisi basah dan kering secara periodik akibat kondisi pasang surut air sungai dan hujan. kondisi pelapukan ini sangat mempengaruhi kestabilan bangunan. Namun dengan disain struktural yang membagi beban ke banyak pondasi telah memberikan keamanan struktur dan mampu bertahan dalam jangka waktu lama.

Pada bagian pondasi ini, ditemukan 2 jenis tiang, yaitu tiang tongkat dan tiang penyambut (lihat gambar 5). Kedalaman tiang tongkat dan tiang penyambut hingga $4 \mathrm{~m}-8 \mathrm{~m}$. Tiang tongkat memiliki ketinggian yang berbeda dengan tiang penyambut. Tiang tongkat didirikan mulai dari tanah sampai ke bagian atas (balok pengaku) sedangkan tiang penyambut didirikan hingga balok struktur lantal. Tiang tongkat utama terletak di empat sudut bangunan induk dan didirikan dengan bahan yang utuh dan menerus dan selanjutnya kolom pada struktur tengah. Untuk menahan tiang tongkat dari beban maka dibutuhkan samge barat untuk menopangnya (lihat gambar 6 a). 


\begin{abstract}
Samge barat menjadi selempang antar pondasi untuk memastikan seluruh tiang tongkat dan tiang penyambut membentuk posisi sudut $90^{\circ}$ agar tiang utama tetap tegak. Samge barat di ikat menggunakan rotan atau dipaku dan dipasang untuk menopang atau menahan tiang tongkat agar tidak goyang dan bergeser akibat beban vertikal dan horizontal (lihat gambar 6 b dan $c$ ). Dengan memperhatikan fungsinya bagi struktur maka sesudah konstruksi, samge barat banyak yang tidak dilepas.
\end{abstract}

Tiang tongkat dan tiang penyambut

diperkuat dengan galang berupa kayu belian (kayu dengan kualitas kelas I) yang dipasang memanjang arah bangunan. Panjang galang ditemukan hingga panjang $12-15$ meter. Posisi galang diletakkan di atas tanah searah memanjang bangunan. Disain galang ini dimaksudkan untuk memperkuat tiang tongkat maupun tiang penyambut agar tidak mengalami penurunan atau pergeseran Akibat gaya horizontal maupun vertikal. Galang yang ditemukan biasanya berbentuk silinder berdiameter 15 - 30 centimeter.

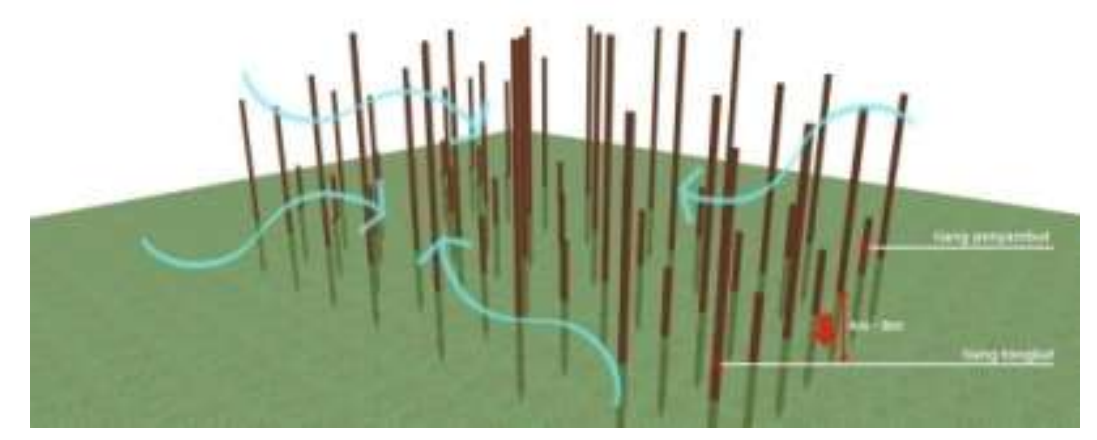

Gambar 5. Posisi tiang tongkat dan tiang penyambut Sumber : Penulis, 2013

(a)

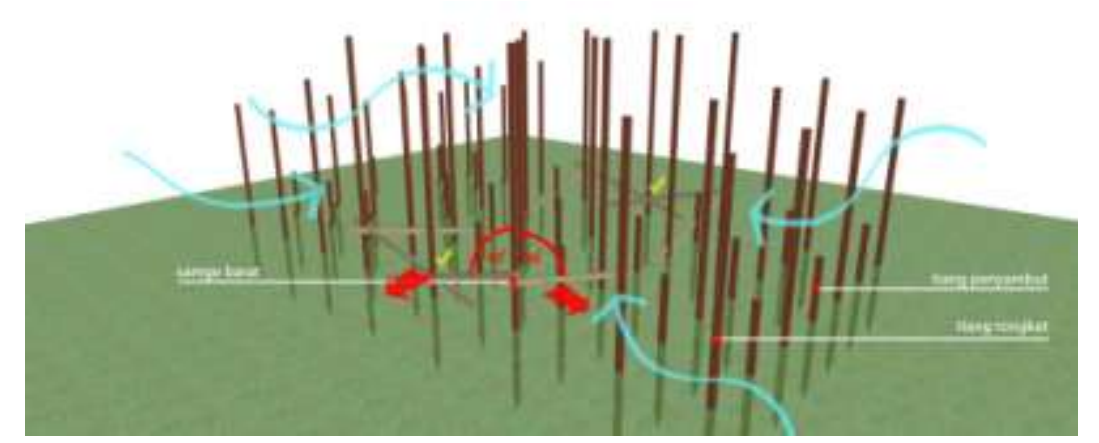

(b)

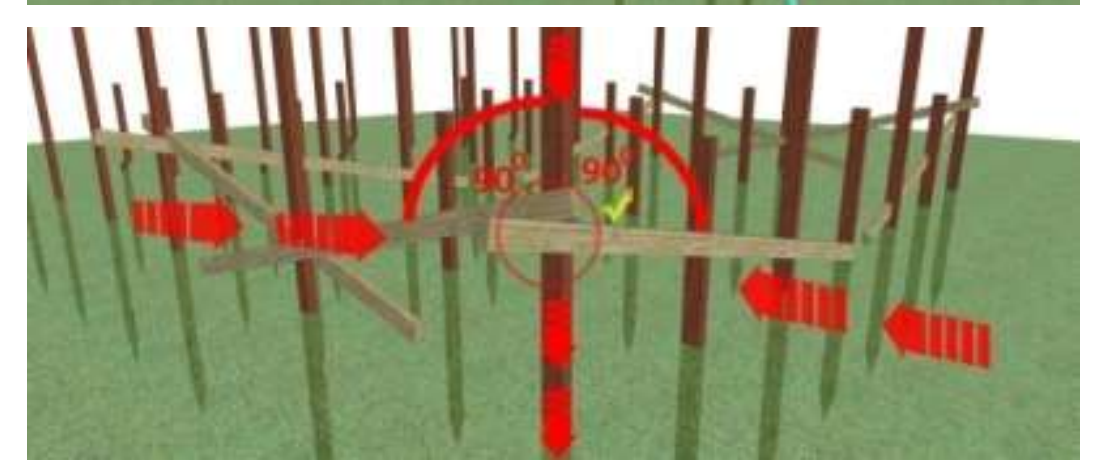

(c)

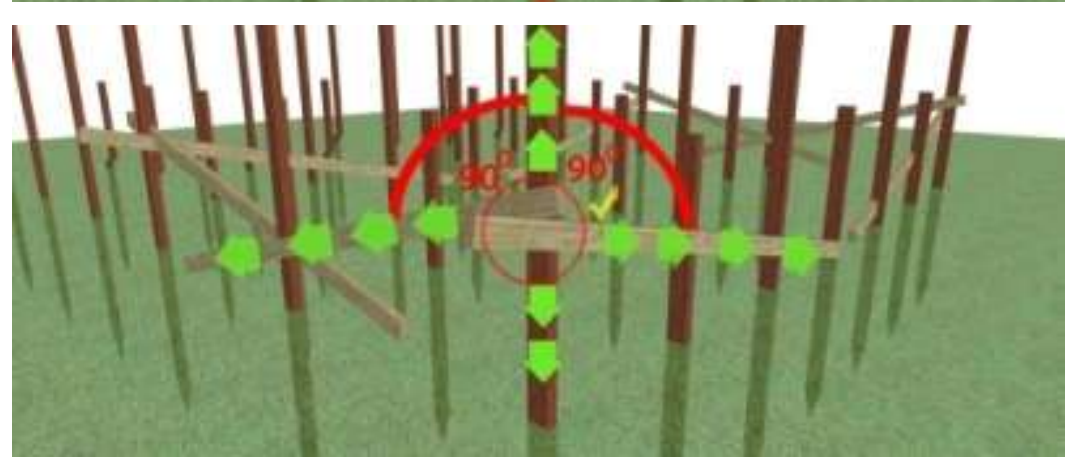

Gambar 6. Posisi samge barat dan reaksi yang dialami terhadap tiang tongkat dan penyambut Sumber : Penulis, 2013 


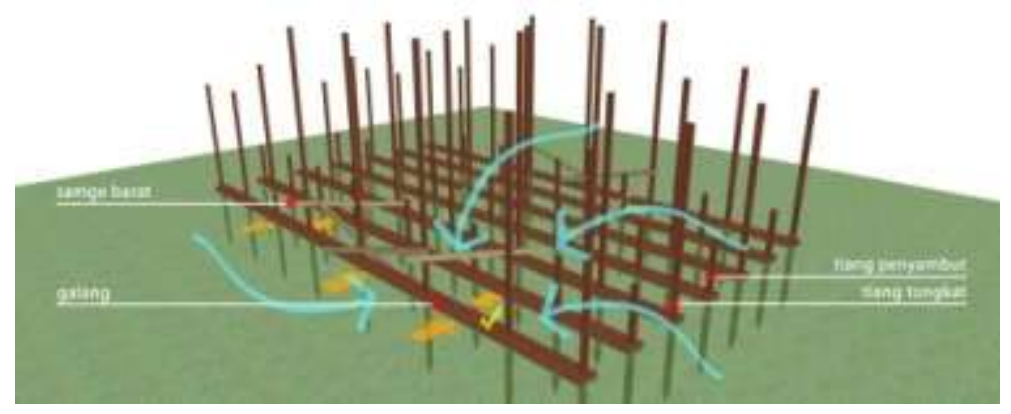

Gambar 7. Disain struktur dan Posisi galang Sumber : Penulis, 2013

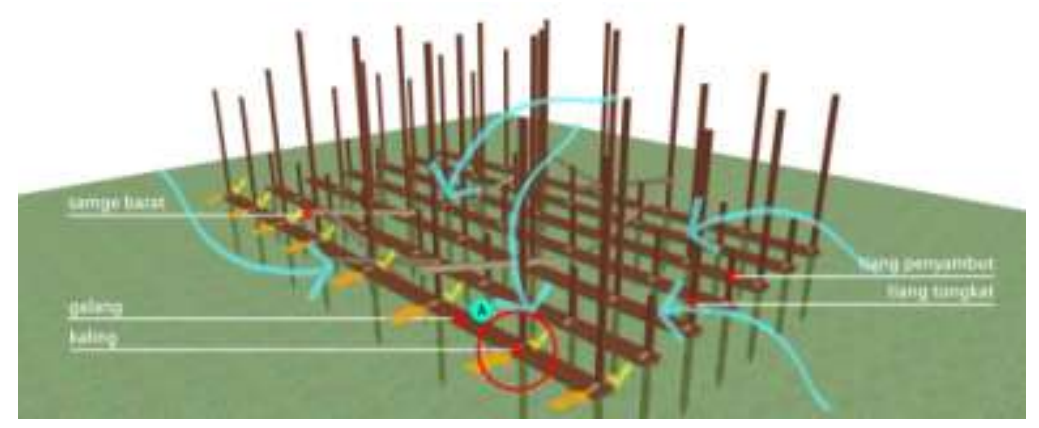

Gambar 8. Disain struktur dan Posisi kaling Sumber : Penulis, 2013

Kaling disebut sebagai kunci pondasi karena fungsi kaling adalah sebagai pengunci atau penyambung tongkat dan galang agar tiang tongkat tetap berdiri kuat dan tegak sehingga kestabilan struktur bawah sangat dipengaruhi oleh kaling. Jumlah kaling mengikuti jumlah tiang tongkat. Posisi kaling melintang bangunan.

Titik A merupakan posisi kaling terhadap tiang tongkat dan tiang penyambut yang membantu dalam beban vertikal maupun horizontal yang dterimanya. Dengan posisi kaling bertumpu pada galang, maka tiang tongkat tidak akan mudah bergeser dan bergoyang. Kedudukan kaling sebagai pengunci sebagai penyeimbang dalam mempertahankan kedudukan tiang tongkat dan tiang penyambut agar tetap berdiri tegak. Sistem yang digunakan antara kaling dan tiang adalah sambungan yang lubang dengan kaling yang menembus ke tiang tongkat (lihat gambar 9). Dengan disain struktur untuk sambungan yang digunakan pada bagian ini, beban yang diterima oleh tiang tongkat menjadi berkurang karena telah disalurkan melalui kaling hingga ke galang dan diredam oleh struktur tanah. Faktor yang mempengaruhi tingkat stabilitas struktur bawah sangat dipengaruhi kekuatan kaling sebagai pengunci atau penyambung tiang tongkat dan galang.

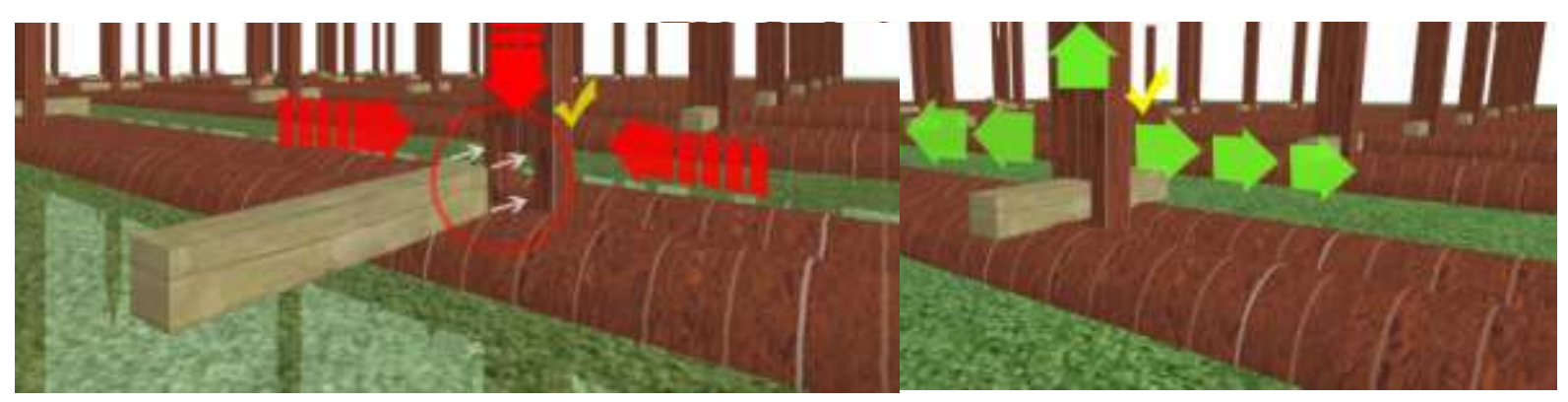

Gambar 9. Disain struktural kaling terhadap galang dan tongkat

Sumber : Penulis, 2013

\begin{tabular}{|c|c|}
\hline $\begin{array}{l}\text { ruktur Tengah } \\
\text { perstructure) }\end{array}$ & $\begin{array}{l}\text { dipasang dengan dengan balok } \\
\text { sambungan yang menembus tongkat, } \\
\text { sedanakan sale menumpu diatas bantalan }\end{array}$ \\
\hline $\begin{array}{l}\text { Kondisi bantalan (balok lantai) d } \\
\text { sale (gelegar lantai) pada semua kas } \\
\text { mengalami pelapukan. sambungan sc } \\
\text { masih kokoh walaupun sebagian tel } \\
\text { lapuk. Pada kasus | dan III, bantal }\end{array}$ & $\begin{array}{l}\text { dengan posisi melintang bangunan. Pada } \\
\text { kasus Il, beberapa sale menumpu di } \\
\text { bantalan dengan ditambah penopang } \\
\text { dibawahnya. }\end{array}$ \\
\hline
\end{tabular}




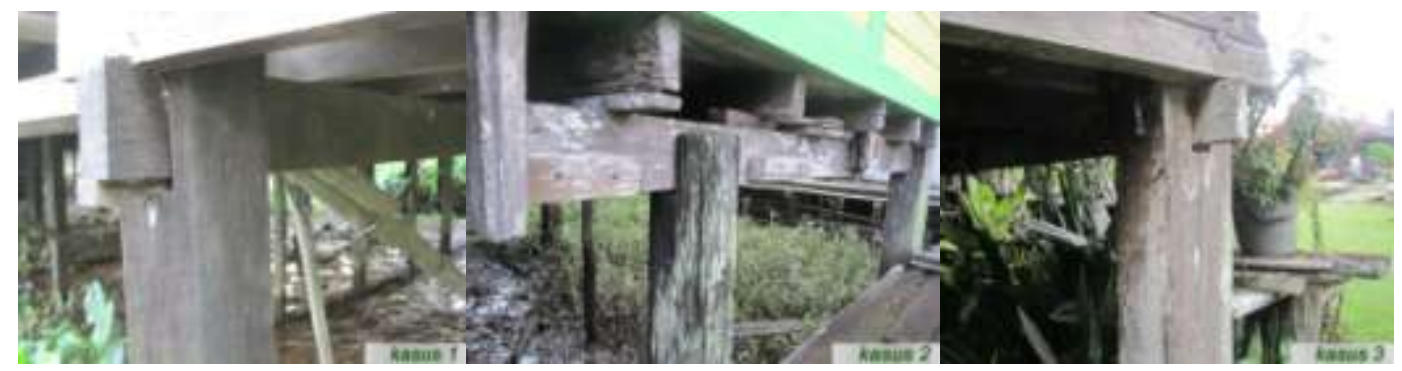

Gambar 10. Kondisi struktur tengah kasus I, II dan III Sumber : Penulis, 2013

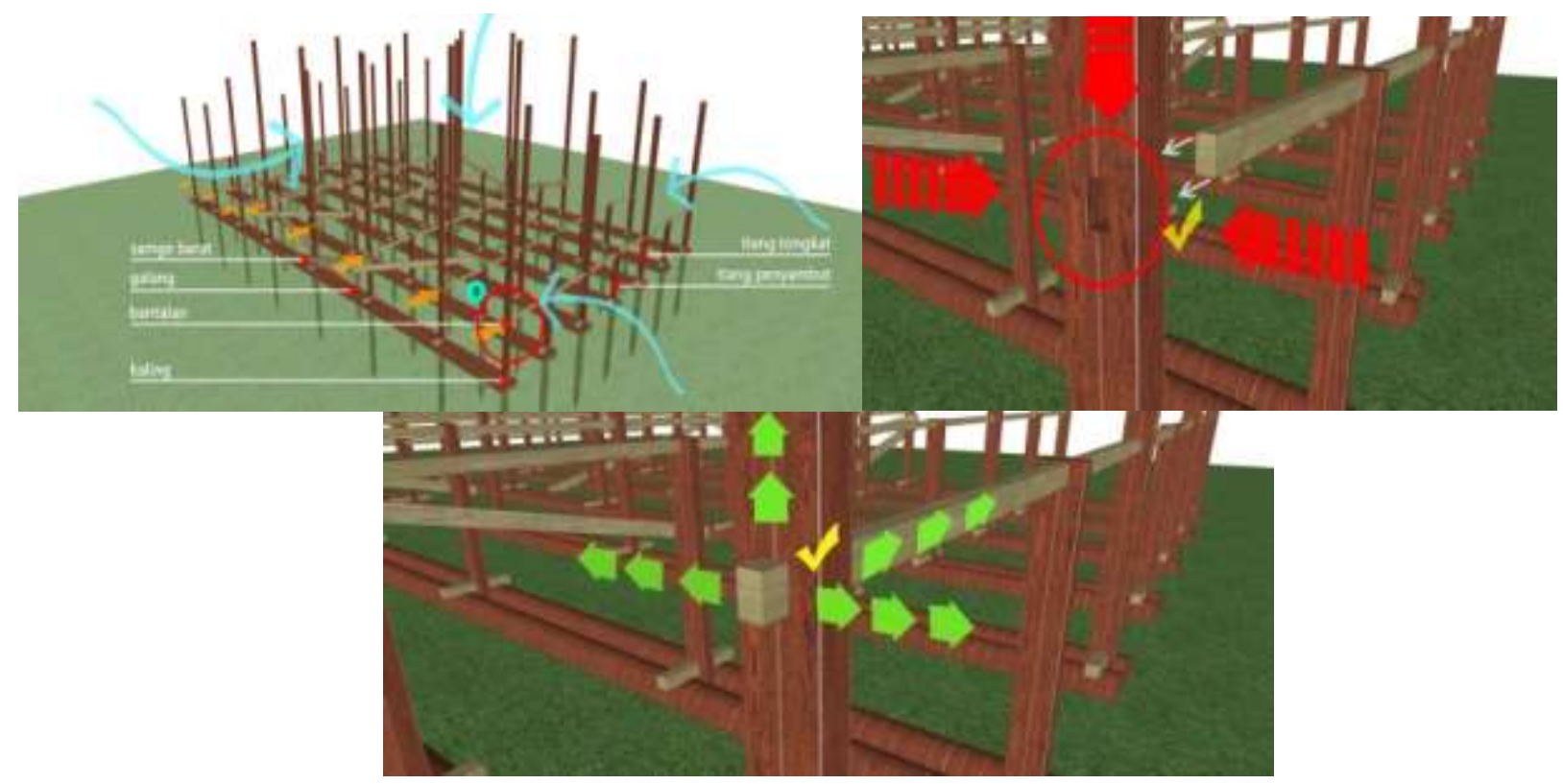

Gambar 11. Disain struktur dan Posisi bantalan Sumber : Penulis, 2013

Bantalan berfungsi sebagai penopang antar tiang tongkat agar tetap tegak, tidak mudah goyang atau bergeser dengan balok berbahan kayu belian Ukuran 15/15 $\mathrm{cm}$ dan elevasi 1,2 - $2 \mathrm{~m}$ dari permukaan tanah. Bantalan juga berfungsi sebagai tumpuan sale. Bantalan dipasang melintang bangunan menggunakan balok panjang seukuran bentang rumah yang berfungsi sebagai balok pengaku. Titik B merupakan posisi bantalan terhadap gaya vertikal dan horizontal dengan balok menggunakan sistem sambungan langsung menembus tiang tongkat (lihat gambar 11). Disain struktur bantalan dengan posisi pemasangan melintang bangunan yang menembus dari ujung ke ujung tiang tongkat semakin memperkaku struktur kolom untuk menahan gaya horizontal maupun vertikal dari semua sisi bangunan. Tingkat stabilitas struktur tengah berawal dari bantalan karena sebagai tumpuan sale dan lantai sebagai sistem struktur bagian bawah.

Rembat dipasang pada posisi di bawah maupun di atas struktur dinding mempunyai fungsi sebagai penopang dinding rumah agar dapat berdiri tegak dan menjadi pengaku struktur lantai bawah maupun lantai parak agar tidak bergeser dan goyang akibat gaya horizontal maupun vertikal (lihat gambar 12). Rembat dipasang menggunakan sambungan lubang dan pen sehingga memperkaku konstruksi dinding dengan lapisan papan sebagai penutupnya.

Sale diletakkan langsung di atas bantalan dengan jumlah yang selalu ganjil dan posisi memanjang bangunan. Titik C merupakan posisi sale terhadap rembat dan bantalan (lihat gambar 12). Sale berbahan kayu belian dan mempunyai ukuran $5 / 10 \mathrm{~cm}$ sampai $10 / 10 \mathrm{~cm}$. Pada titik $\mathrm{C}$, sale menumpu ke bantalan untuk menahan beban dari lantai bawah dan lantai parak dan beban di atasnya. Titik D merupakan posisi rembat bawah terhadap gaya vertikal dan horizontal. Fungsi yang sama ditunjukkan oleh rembat yang diletakkan di atas atau bawah. Rembat dan dinding dihubungkan dengan sambungan lidah (lihat gambar 12). Disain struktur ini diperoleh dengan cara papan yang sudah dibuat dengan profil lidah dimasukkan dari sisi kanan satu per satu dan begitu seterusnya hingga ke sisi kiri. Oleh karena itu, jika dinding papan ada yang renggang atau lapuk hingga akhirnya terlepas maka seluruh struktur dinding akan terlepas semuanya. 


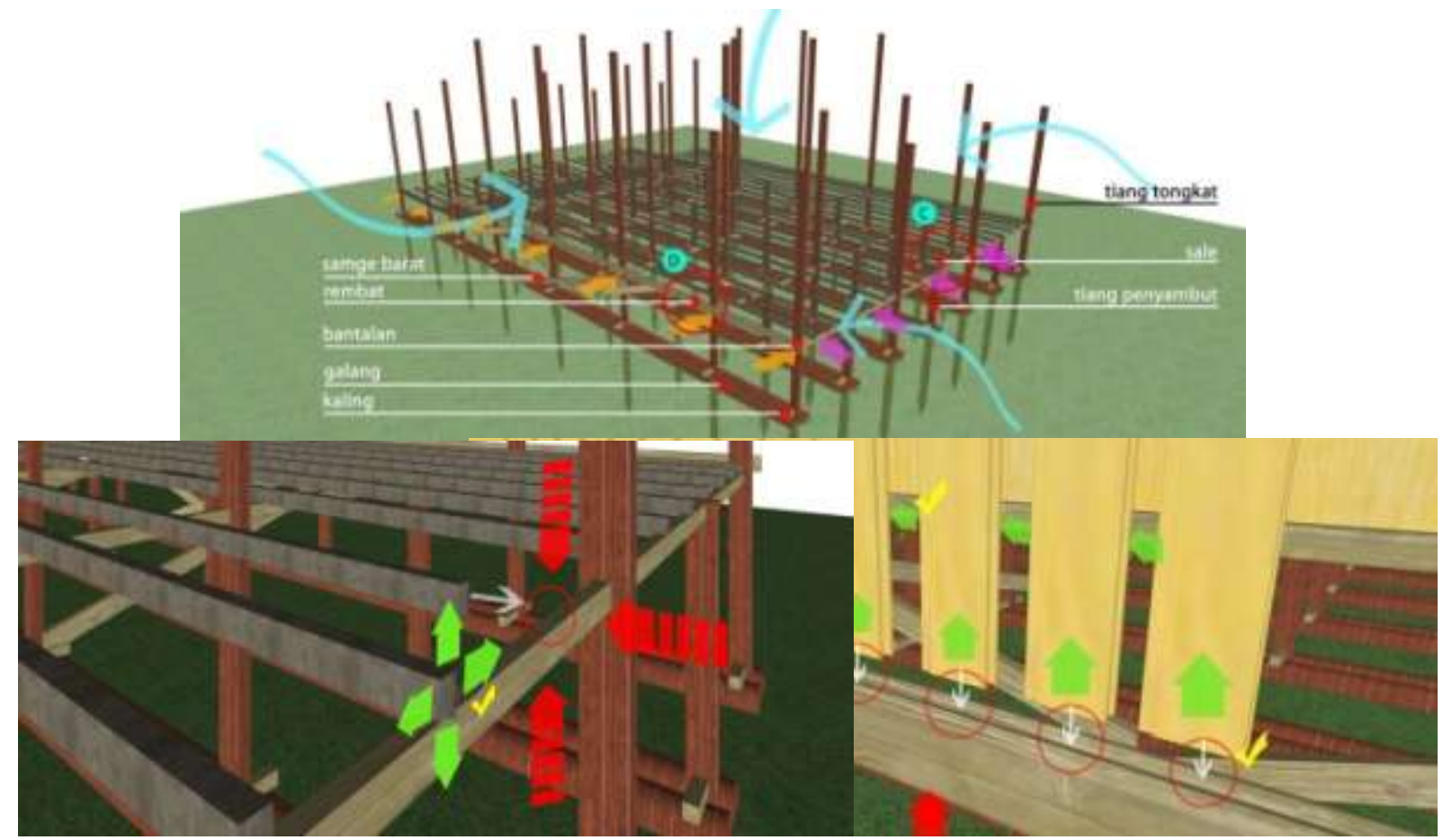

Gambar 12. Disain struktur rembat bawah, sale bawah dan dinding Sumber : Penulis, 2013

\section{Struktur atas (upper side super structure)}

Titik E pada gambar 14 memperlihatkan posisi rembat atas. Disain struktur rembat atas memiliki fungsi yang sama dengan rembat bawah sebagai pengaku struktur dinding rumah agar dapat berdiri tegak dan penopang struktur lantai parak dan kuda-kuda agar tidak bergeser dan goyang terkena gaya horizontal maupun vertikal. Gambar tersebut menunjukan hubungan rembat atas dan sale atas yang menumpu satu sama lainnya.

Rembat atas memiliki fungsi sama seperti bantalan yakni menahan agar tiang-tiang tongkat (kolom) tidak terlepas satu sama lain untuk menjaga kestabilan bangunan sepanjang masa konstruksi. Rembat atas dipasang memanjang maupun melintang bangunan menggunakan kayu belian dengan ukuran bervariasi antara $5 / 10 \mathrm{~cm}$ hingga $10 / 10 \mathrm{~cm}$. Titik $F$ pada gambar 15 memperlihatkan balok pengaku. Balok pengaku pada struktur atas berfungsi sebagai penahan agar tiang-tiang tongkat tidak mudah lepas. Selain itu balok pengaku juga berfungsi sebagai tumpuan balok kuda-kuda. Balok kuda-kuda berfungsi sebagai penumpu girring-girring. Pada gambar 15 memperlihatkan titik $G$ sebagai posisi girring-girring yang berfungsi sebagai balok vertikal penumpu tulang bumbungan rumah.

$$
\text { Untuk menahan konstruksi }
$$

keseluruhan rangka atas, di disain elemen struktur samge barat atas dengan fungsi seperti ikatan angin pada kuda-kuda modern. Sama seperti pemasangan samge barat bawah, pada konstruksi struktur atas samge barat atas dipasang dengan cara diikat dengan rotan untuk menopang balok vertikal agar kokoh.

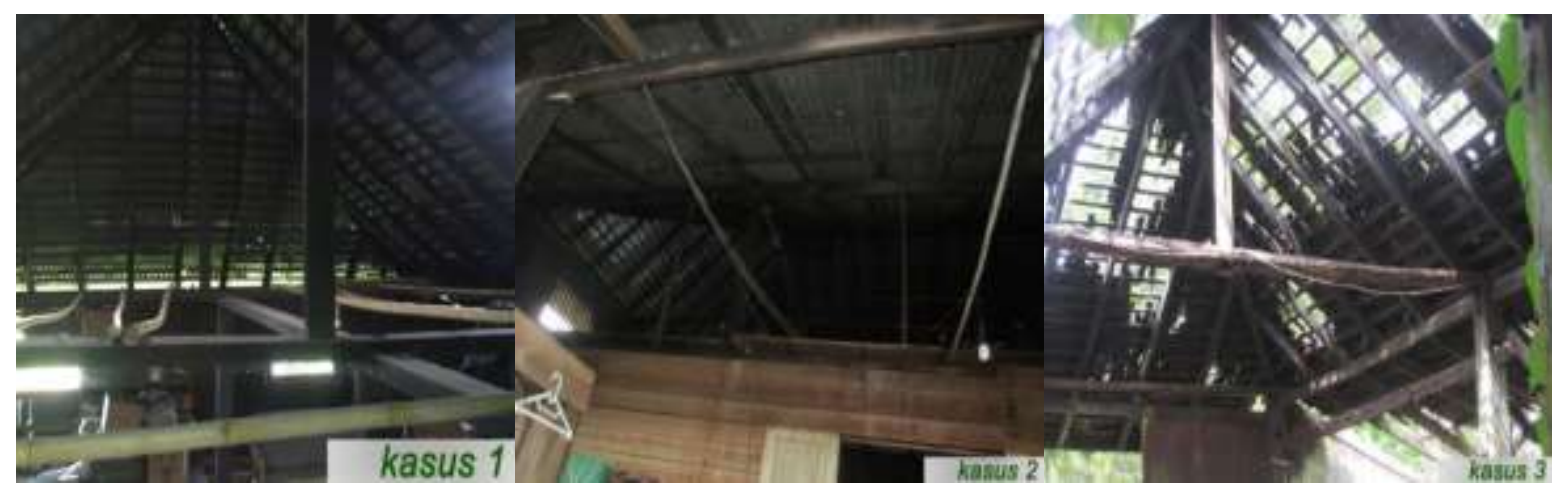

Gambar 13. Kondisi Struktur Atas Kasus I,II Dan III Sumber : Penulis, 2013 


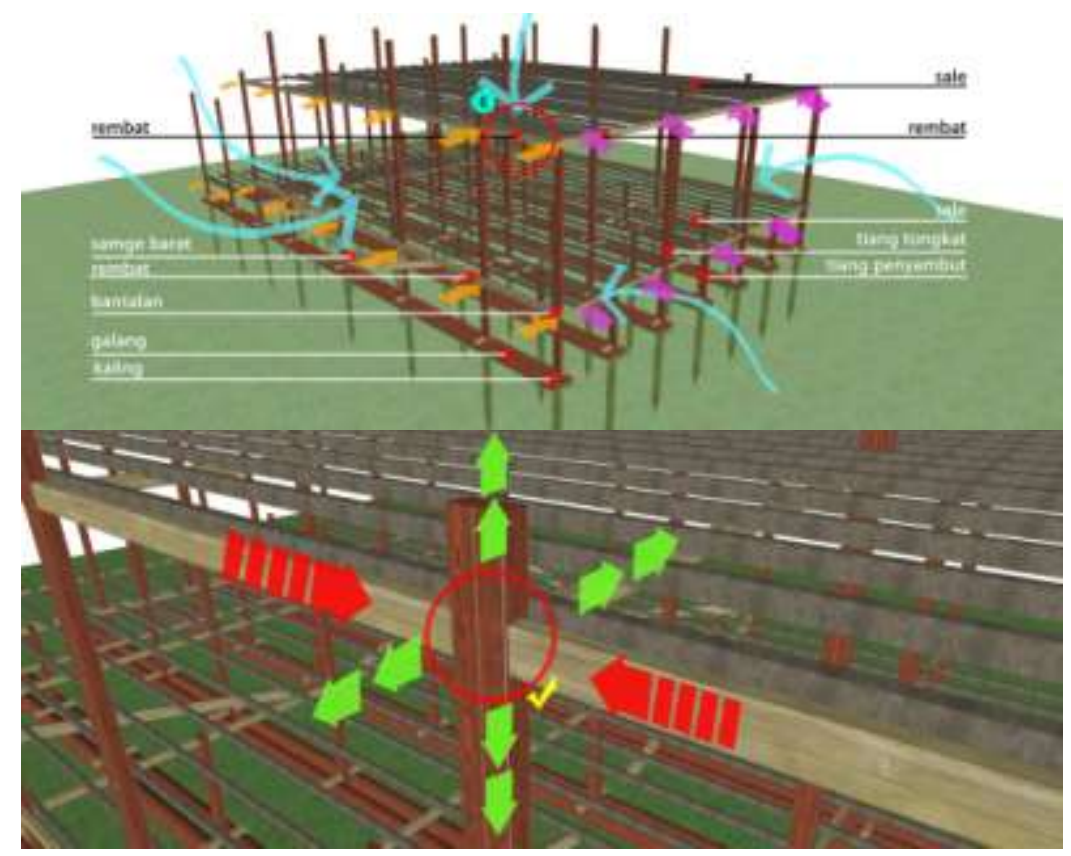

Gambar 14. Disain struktur serta letak rembat atas dan sale atas Sumber : Penulis, 2013

Pada gambar 15 diperlihatkan juga titik $F$, balok bumbungan di disain untuk menahan tiang vertikal struktur atas dan disambung dengan sistem sambungan lubang dan pen. Tiang vertikal struktur atas ini juga ditahan oleh balok pengaku baik melintang maupun memanjang pada sisi bawahnya (lihat gambar 15). Balok pengaku sebagai pengaku tiang vertikal struktur atas ini merupakan balok yang sama dengan tiang tongkat. Kondisi ini menjadikan struktur atas tidak bergeser dan bergoyang terkena gaya vertikal dan horizontal yang dialami struktur bangunan dari depan maupun belakang bangunan.

Titik $\mathrm{H}$ merupakan sambungan kasau dan gording dengan posisi gording ukuran $10 / 15 \mathrm{~cm}$ dipasang menumpu pada kasau ukuran $15 / 15 \mathrm{~cm}$ (lihat gambar 15). Sistem sambungan pada gording merupakan sambungan langsung terhadap kasau dan dikunci oleh pasak. Gording di disain menumpu dan dipasakkan pada rangka struktur atas untuk selanjutnya menumpu kasau. Demikian juga dengan kasau, di disain untuk ditempatkan dengan lubang pada gording dan kemudian diberi pasak. Begitu selanjutnya untuk semua titik pertemuan antara gording dan kasau diberi pasak yang dilakukan untuk memperkuat sambungan antara gording dan kasau.

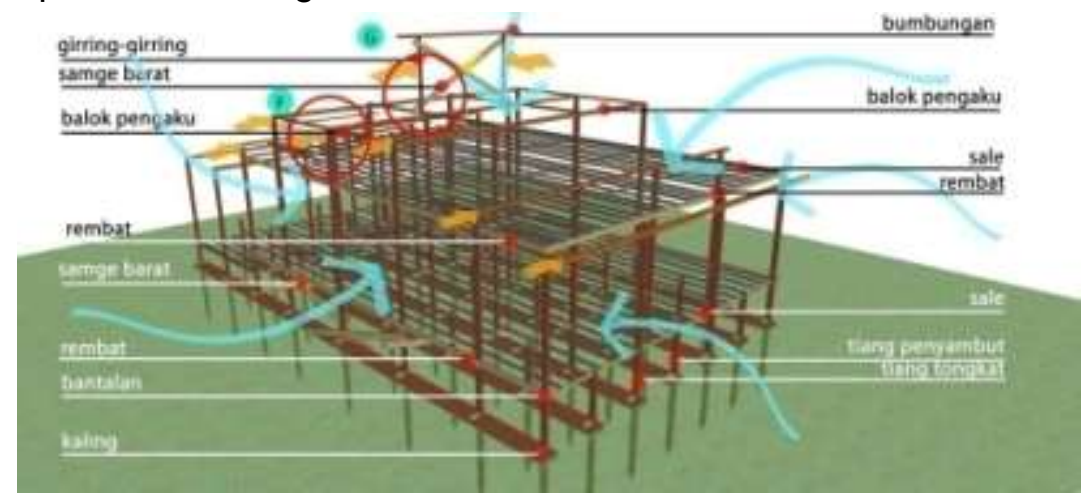

Gambar 15. Disain struktur serta Posisi balok pengaku dan girring-girring Sumber : Penulis, 2013
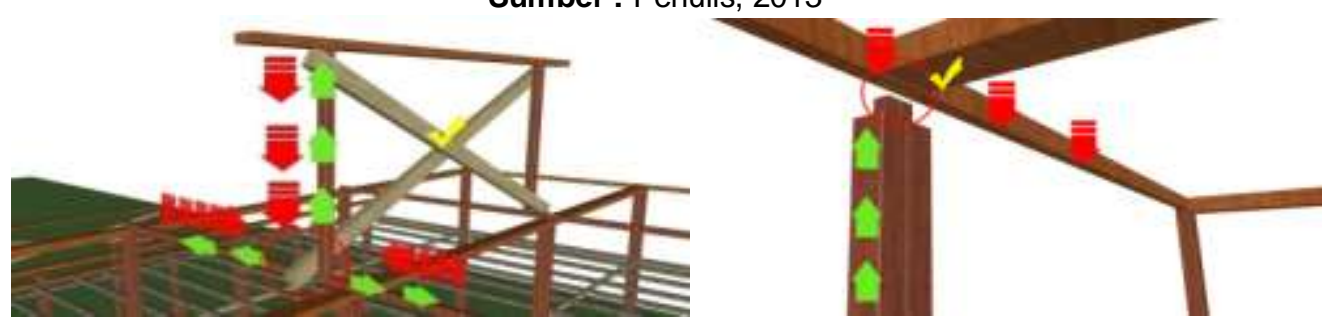

Gambar 16. Disain struktur dan Posisi girring-girring

Sumber : Penulis, 2013 


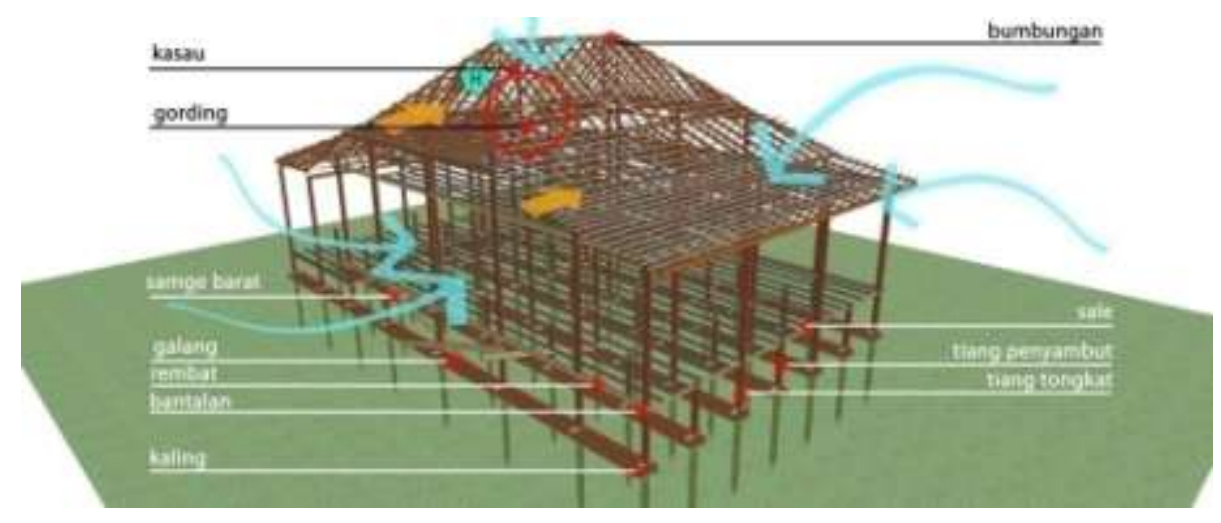

Gambar 17. Disain struktur dan Posisi kasau dan gording Sumber : Penulis, 2013

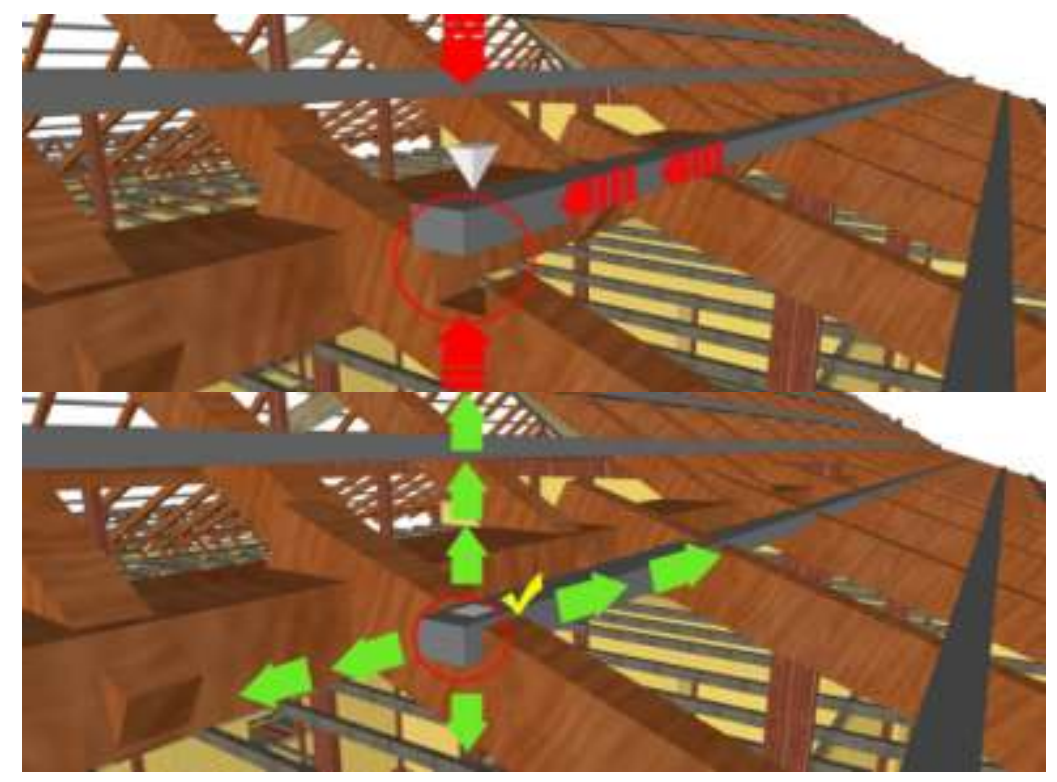

Gambar 18. Disain struktur dan posisi kasau dan gording terhadap struktur atas Sumber : Penulis, 2013

Ketika sambungan telah terpasang maka konstruksi atap menjadi tidak bergoyang atau bergeser karena semua titik pertemuan antara gording dan kasau yang diberi pasak, sehingga menjadikan konstruksi atap kuat dan kestabilan bangunan akan terjaga. Posisi pasak dari setiap pertemuan penutup atap dapat mempertahankan stabilitas struktur dan di setiap pertemuan sisi atas akan ditutupi dengan perabung (lihat gambar 19). Atap sirap menggunakan bahan kayu belian yang di belah dengan ketebalan $0,5 \mathrm{~cm}$. Tulang bumbungan yang berada di bawah perabung dipasang pada arah melintang bangunan berfungsi sebagai pengaku akibat gaya tekan yang dialami atap.

Pada gambar 19, Titik I memperlihatkan posisi sambungan pada atap sirap. Pada saat pemasangan sirap, atap sirap menumpu pada kasau dan dikunci dengan pasak yang dipasang pada setiap pertemuan sirap dari sisi atas maupun bawah sehingga struktur antar sirap dapat tertumpu dengan sempurna. Dengan disain struktur ini, konstruksi atap menjadi stabil terhadap gaya vertikal dan horizontal karena seluruh penutup atap tertumpu pada kasau.

\section{Disain Struktural Rumah Tradisional}

Sejalan dengan yang disampaikan Wahl (2007: 8-9), bahwa disain struktural pada rumah tradisional Melayu di kota Sambas juga mengedepankan tujuantujuan yang diharapkan oleh penghuninya. Berikut ini fakta-fakta yang didapat dari pembahasan tentang rumah tradisional Melayu di kota Sambas yang dikaitkan dengan tujuan disain struktural bangunan menurut Wahl. Sama seperti bangunanbangunan lainnya, rumah tradisional Melayu di kota Sambas juga di disain dengan struktur bangunan untuk memenuhi tujuan-tujuan safety, values, fitness, compatibility dan flexibility. seluruh tujuan-tujuan ini akan memberikan perlindungan total kepada penghuninya untuk beraktivitas, penyesuaian dengan keadaan internal/eksternal dan mengakomodir kebutuhan yang diharapkan oleh penghuni untuk tinggal dengan nyaman. 


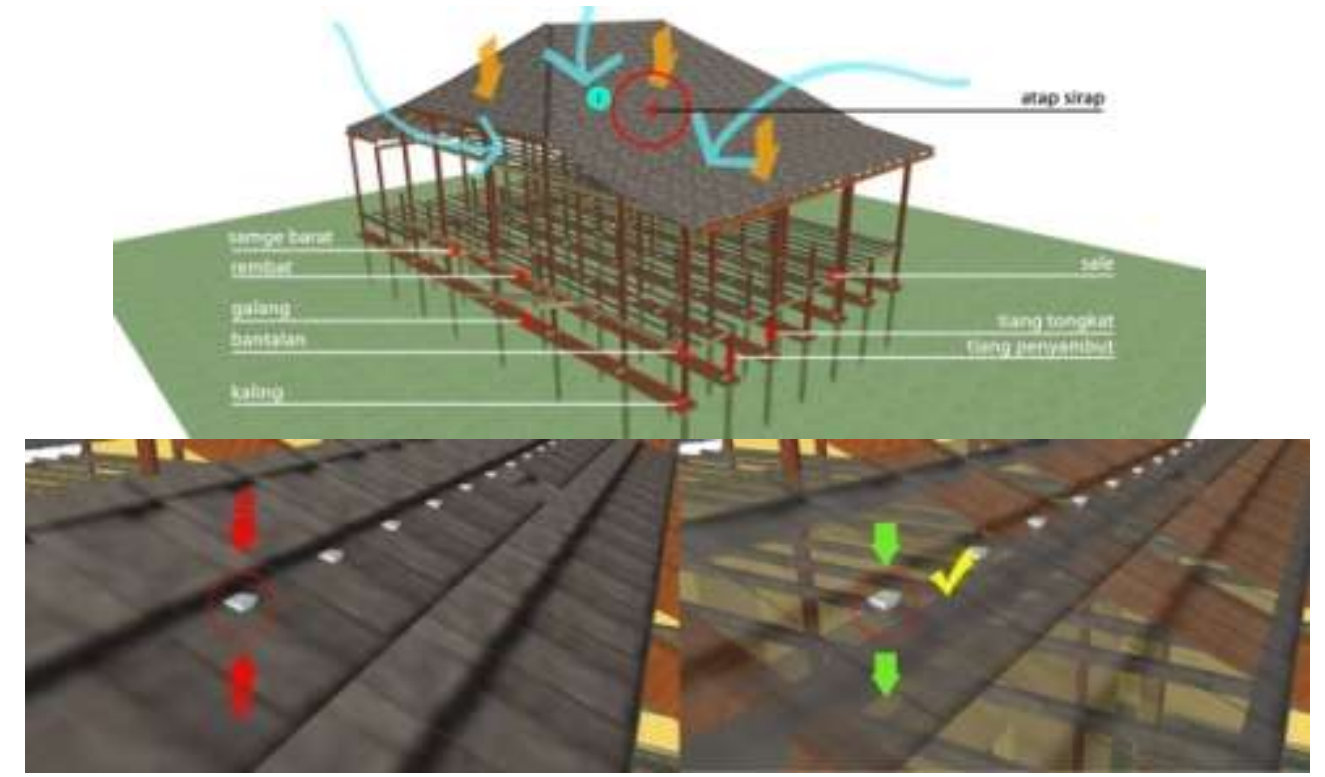

Gambar 19. Disain struktur atas bangunan tradisional Melayu di Kota Sambas Sumber : Penulis, 2013

Safety, rumah tradisional Melayu di kota Sambas menyediakan tempat penampungan yang aman dan menjadi perlindungan dari bahaya bagi penghuni; Sejalan dengan Zain (2012a), keadaan ini dihasilkan dari:

- kedominanan yang diberikan pada bangunan baik secara vertikal maupun horizontal menurut tekstur, atau elemen pembentuk fasad. Dari hasil penelitian ini, ditemukan bahwa kekokohan dan kekuatan struktur tercipta dengan penonjolan struktur tongkat untuk pondasi bangunan serta bentuk-bentuk dasar seperti persegi panjang dan segitiga mendominasi bentukan yang dibuat menjadikan bangunan ini memiliki kestabilan yang tinggi;

- Proporsi, komposisi yang tersusun secara harmonis yang hendak ditonjolkan bangunan. Proporsi dapat dilihat dari bentuknya yang simetris atau asimetris bangunan tersebut. Bentuk yang simetris menjadikan struktur menjadi stabil. Fasad bangunan rumah induk dan rumah anak yang simetris menjadikan struktur stabil menerima bebannya. Bentuknya yang simetris merupakan bagian dari penempatan kolom-kolom yang simetris dan menjamin kestabilan struktur sehingga ketahanan (durability) bangunan lebih tinggi akibat pengaruh beban sendiri; dan

- Keseimbangan, berkaitan dengan fungsi, struktur serta pembentukan massa yang seimbang. Keseimbangan bangunan baik secara melintang maupun memanjang bangunan menjadi struktur stabil dan memudahkan dalam pembentukkan ruang.

Value, disain struktur rumah tradisional Melayu di kota Sambas menjadi nilai yang sesuai dengan keinginan penghuni. Tujuan ini dicapai dari konstruksi atap dibuat dengan kemiringan atap lebih tinggi untuk membuat ruang pada parak. Ruang-ruang di rumah tradisional Melayu di kota Sambas dapat dibentuk dengan memindahkan sekat berdasarkan bentang kolom yang terbentuk. Keterhubungan antara teras hingga dapur/pelataran juga di disain untuk memudahkan apabila diadakan acara sehingga bisa menampung orang dalam jumlah yang cukup.

Kolom yang menempel pada bidang dinding memberikan artikulasi pada permukaan dinding tersebut. Kolom-kolom tersebut memperkuat sudut suatu ruang dan mengurang efek pertemuan bidangbidang dinding. kolom ini menetapkan daerah-daerah yang bisa dibentuk dalam sebuah ruangan.

Dominasi kolom-kolom vertikal dengan fleksibilitas penambahan pada semua ruang dimaksudkan memberikan arah sirkulasi di dalam ruangan dan memberikan kesan kekokohan bangunan. Kolom-kolom dengan ketinggian yang berkisar antara 3,5 meter hingga 4 meter menambah kemegahan bangunan. Struktur rangka yang kaku dengan bukaan memberi irama pada setiap ruangan.

Kolom-kolom di serambi tengah dan belakang memperkuat volume ruang yang hendak dibentuk sedangkan kolom-kolom lainnya berfungsi sebagai pembatas ruang membentuk bidang dinding. Susunan tersebut mengurangi skala ruang, membantu membuat dimensinya lebih dapat dimengerti dan menentukan daerah ruang didalamnya.

Fitness, disain struktur rumah tradisional Melayu di kota Sambas disesuaikan dengan kondisi spesifik site bangunan, dan memenuhi persyaratan program sirkulasi internal dan fungsi pada bangunan. Pemilihan tiang tongkat untuk membuat elevasi lantai bangunan juga mengantisipasi kondisi site bangunan berada di tanah lunak (tepian sungai), 
pasang surut air sungai dan gangguan binatang. Pemasangan galang untuk menumpu tiang tongkat yang berbedabeda pada rumah tradisional Melayu di kota Sambas dimaksudkan untuk menahan beban angin yang dapat mengangkat dan menggulingkan struktur pada saat angin kencang. Selain itu, pemasangan galang ini di disain bergantung dengan posisi kuda-kuda, arah hadap permukaan atap terhadap arah angin dan arah aliran sungai sebagai orientasi rumah tersebut.

Dinding-dinding sejajar pada suatu struktur dinding pemikul menjadi kekuatan pembentuk bangunan dan organisasinya. Pola pengulangannya diubah dengan membedakan panjangnya dan memberikan bukaan-bukaan pada bidang untuk mencukupi kebutuhan dimensi ruang yang besar.

Deretan tiang-tiang, membatasi sisisisi suatu suatu volume ruang disamping membiarkan adanya kontinuitas visual maupun ruang, antara ruang-ruang yang ada dengan keadaan disekelilingnya. Selain itu, kondisi ini juga untuk pemenuhan persyaratan program sirkulasi internal dan fungsi-fungsi ruang pada bangunan.

Compatibility, disain struktural rumah tradisional Melayu di kota Sambas mampu terintegrasi dengan keseluruhan sistem internal dan eksternal bangunan. Disain struktur ruang parak memberikan ruang bebas dibagian atas antara atap dengan lantai parak. Ketinggian atap 4 meter dari lantai parak menjadikan ruangan dibawahnya lebih sejuk dan lantai bangunan yang berupa papan menjadikan udara dapat mengalir dari celah-celah papan dan udara dapat mengalir dari bawah hingga ke atas. Bahan penutup atap berupa sirap membuat sinar matahari yang menimpanya tidak diserap tetapi dipantulkan sehingga ruangan dibawahnya tidak panas. Orientasi bangunan yang menghadap sumbu Utara - Selatan juga membantu pengaliran udara dan masuknya sinar matahari yang nyaman di dalam ruangan.

Disain bentuk atap yang curam juga memberikan kemudahan untuk air hujan mengalir dengan segera pada musim hujan. Data tahun 2009 curah hujan yang dipublikasikan oleh Badan Pusat Statistik Kalimantan Barat (2010: 42-430 menyebutkan bahwa curah hujan rata-rata setiap bulan berada pada kisaran 259.58 millimeter per bulan. Curah hujan tertinggi terjadi di pertengahan Oktober hingga Januari dalam kisaran rata-rata 342.6 millimeter - 485 millimeter, sementara curah hujan terendah terjadi di pertengahan Juni hingga September dalam kisaran rata-rata 115.96 millimeter 255.57 millimeter. Data ini sejalan dengan pendapat Tahir (2010: 49) bahwa kemiringan atap yang curam dipilih sebagai disain struktur rumah tradisional Melayu yang tepat untuk penyesuaian dalam beradaptasi dengan kondisi alam

\section{setempat}

Flexibility, fleksibilitas kemampuan struktur yang di disain pada rumah tradisional Melayu di Kota sambas dalam memprediksi kebutuhan fungsi terhadap masa utilitas bangunan dan kondisi site di masa depan. Susunan ruang pada rumah tradisional Sambas diarahkan pada penggunaan ruang secara bersamaan agar dapat menampung orang dalam jumlah yang banyak. Adanya ruang yang saling berkaitan satu dengan lain membuat ruang dapat bermanfaat sebagai ruang acara adat seperti selamatan, pernikahan, tahlilan dan sebagainya. Susunan ruang yang mempunyai luas ruang-ruang publik dan semi privat yang lebih besar dibandingkan ruang privat, memang dimaksudkan untuk memudahkan dalam penggunaan untuk acara adat. Disain struktur ruang dalam rumah yang fleksibel akan memudahkan penghuni menambah atau mengurangi ruangan sesuai dengan kebutuhan. Selain itu, sistem struktur dan jenis material yang digunakan juga sangat membantu dalam menambah masa utilitas bangunan.

\section{Kesimpulan}

Rumah tradisional Melayu di kota Sambas juga di disain dengan struktural bangunan yang dikerjakan dalam memenuhi tujuan-tujuan:

- Safety diperoleh dari keadaan yang memperhatikan kedominanan, proporsi dan keseimbangan;

- Value diperoleh dari perhatian terhadap konstruksi ruang, keterhubungan ruang, susunan dan perletakan kolom;

- Fitness diperoleh dari pemilihan dan pola struktur;

- Compatibility diperoleh dari perhatian terhadap pemilihan material, orientasi bangunan dan bentuk-bentuk struktur ruang; sedangkan

- Flexibility diperoleh dari susunan dan keterkaitan ruang serta pemilihan sistem struktur.

\section{Ucapan Terima kasih}

Terima kasih kepada ketua dan civitas akademika di Program Studi Arsitektur Fakultas Teknik Universitas Tanjungpura yang telah banyak memberikan masukan dan dukungan pada proses penulisan artikel ini.

\section{Referensi}

AlMudra, Mahyudin. 2004. Rumah Melayu Memangku Adat Menjemput Zaman. Balai Kajian Dan Pengembangan Budaya Melayu. Yogyakarta

Bappeda Kab. Sambas, 2012. Rencana Tata Ruang dan Wilayah Kabupaten Sambas 2012-2032. Bappeda Kab. Sambas. Sambas

BPS-Kalimantan Barat. 2010. Kalimantan 
Barat Dalam Angka 2010. Badan Pusat Statistik Provinsi Kalimantan Barat. Pontianak

Noble, Allen G. 2007. Traditional Buildings A Global Survey of Structural Forms and Cultural Functions. I.B.Tauris \& Co Ltd, New York

Tahir, M. M.; M. F. M. Zain; K. Sopian; I. M. S. Usman; M. Surat; N. A. G. Abdullah; N. Tawil; M. F; I. Md Nor, A. I. Che-Ani. 2010. The development of a sustainably responsive ultra low energy terrace housing for the tropics incorporating the raised floor innovation. Proceedings of the 5th IASME / WSEAS International Conference on ENERGY \& ENVIRONMENT (EE '10) University of Cambridge, United Kingdom p. 36-45, Energy and Environmental Engineering Series: A Series of Reference Books and Textbooks. Published by WSEAS Press.

Wahl, Iver. 2007. Building Anatomy : An Illustrated Guide to How Structures Work. Mc.Graw Hill Company Inc. New York

Zain, Zairin; Indra Wahyu Fajar. 2014.

Tahapan Konstruksi
Tradisional Suku Melayu Di Kota
Sambas Kalimantan Barat. Jurnal
Langkau Betang Volume 1 Nomor 1
Tahun 2014. Program Studi Arsitektur
Fakultas Teknik Universitas Tanjungpura
dan Pusat Studi Disain Universitas
Tanjungpura. Pontianak

Zain, Zairin. 2013. The Anatomy of traditional Dwellings: Comparative Study between Malay and Dayak Indigenous Architecture in West Kalimantan. LAP Lambert Academic Publishing/AV Akademikerverlag $\mathrm{GmbH}$ \& Co. KG. Saarbrücken. Germany

Zain, Zairin. 2012a. Pengaruh Aspek Eksternal Pada Rumah Melayu Tradisional di Kota Sambas. Jurnal NALARs, Vol 11 No 2 Juli 2012. Universitas Muhammadiyah Jakarta. Jakarta

Zairin Zain. 2012b. Analisis Bentuk dan Ruang pada Rumah Melayu Tradisional di Kota Sambas, Kalimantan Barat. Jurnal NALARs Volume 11 No. 2 Universitas Muhammadiyah Jakarta. Jakarta 